\title{
Syntheses of Alarm Pheromone Analogues of the Mold Mite, Tyrophagus putrescentiae, and Their Biological Activities ${ }^{\dagger}$
}

\author{
Yasumasa Kuwahara and Lica SaKuma* \\ Institute of Applied Biochemistry, University of Tsukuba, \\ Sakura, Nihari, Ibaraki 305, Japan \\ Received January 18, 1982
}

\begin{abstract}
Against the mold mite, Tyrophagus putrescentiae, 3,7-dimethyl-(Z)-2-octenyl formate (II) is the most active compound as an alarm pheromone besides the natural pheromone, neryl formate (I), and this activity is equal to $\mathbf{I}(1 \sim 10 \mathrm{ppm})$. In order to elucidate the structural requisites for inducing alarm pheromone activity, a total of 16 analogues of $\mathbf{I}$ were prepared by modifying the structure of II. For preparation of 3-methyl- and 3-ethyl-(Z)-2-alkenyl formates, the Wittig reaction of ethoxy- or methoxy-carbonylmethylene triphenyl phosphorane with 2-alkanone or 3alkanone was used. The reaction with 2-alkanone gave a mixture of $(Z)$-2-alkenoate $(\mathrm{ca.} 40 \%$ and $(E)$-2-alkenoate $(\mathrm{ca} .60 \%)$ in an average $60 \%$ yield. The reaction with 3 -alkanone gave a mixture of $(Z)$-2-alkenoate $(56 \%)$ and $(E)$-2-alkenonate $(44 \%)$.

Alarm pheromone activities were demonstrated on 14 compounds of $(Z)$-2-alkenyl formates. The presence of the $(Z)$-allylic primary alcohol formate moiety in a molecule was clarified as the key to induce pheromone activity, and no necessity for an acyclic monoterpene carbon skeleton was demonstrated.
\end{abstract}

The mold mite, Tyrophagus putrescentiae (Schrank) is known as one of the most commonly distributed sarcopiformes mites for attacking stored grain and its products. This mite emits a characteristic smell when squashed, and its principle component, which was identified as neryl formate (I), ${ }^{1)}$ was determined as the alarm pheromone. ${ }^{2)}$ Citral was also identified as a minor component of the pheromone. ${ }^{3)}$ Through a bioassay of the monoterpenoids, the pheromone activity was only found in nerol and its derivatives. The following decreasing order of activity was observed among the four functional groups and derivatives; formate > aldehyde $>$ alcohol $\fallingdotseq$ acetate. ${ }^{3)}$ A further study on the structure-activity relationship revealed that the $(Z)$-allyl primary alcohol moiety in an aliphatic monoterpene structure was required for developing the activity. ${ }^{4)}$ Among the synthetic monoterpenoids which contained the requisite moiety, 3,7dimethyl-( $Z$ )-2-octen-1-ol and its formate (II) were demonstrated to have pheromone activity. In particular, the formate (II) exhibited the same level of activity as the natural pheromone. $^{4)}$

In order to test the need for an open chain monoterpenoid carbon skeleton, three groups of non-terpenoid pheromone analogues (a total of 16 compounds) were synthesized, and their biological activity were determined.

The modification processes are summarized in Fig. 1. Pheromone activities were only determined on formates, although all formates were prepared from their corresponding alcohols. $(E)$-Analogues were also prepared and their activities were monitored, but none of the compounds indicated any activity.

3-Methyl-(Z)-2-alkenyl formates (III $\sim \mathbf{X}$ ) were synthesized using a Wittig reaction between ethoxycarbonylmethylene triphenyl

† Pheromone Study on Acarid Mites. Part IX. For Part VIII, see ref. 9.

* Present address: Hoechst Japan Co., Ltd., 8-10-16, Akasaka, Minato-ku, Tokyo 107, Japan. 


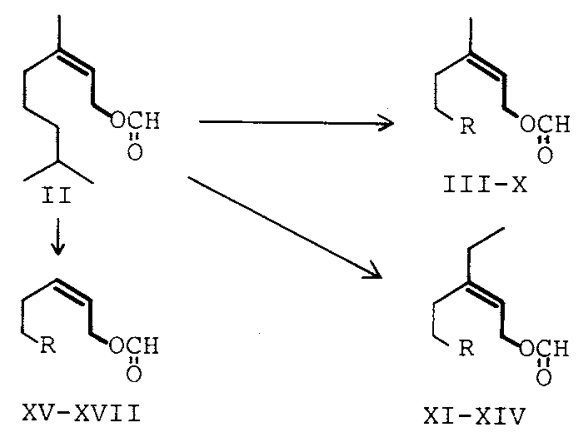

FIG. 1. Summary of the Structural Modification Process from 3,7-Dimethyl-(Z)-2-octenyl Formate (II).

phosphorane (ethoxycarbonyl ylid) or methoxycarbonylmethylene triphenyl phosphorane (methoxycarbonyl ylid) and appropriate 2-alkanones, separation of the $(Z)$ - and $(E)$-alkenoate, reduction with $\mathrm{LiAlH}_{3}-(\mathrm{OEt})^{5)}$ and subsequent formylation. ${ }^{6)}$ The Wittig reaction product of these ylids with alkanal has been known to exclusively give $(E)-2-$ alkenoate. $^{7)}$ However, in the present study with 2-alkanone, a mixture of $(Z)$ - and $(E)$ alkenoates (average ratio of $(Z)$ to $(E)$ was 38 to 62$)$ was obtained in a satisfactory yield $\left(53 \sim 66^{\circ} \%\right.$, from ketones) at $150^{\circ} \mathrm{C}$ without a solvent, when ethoxycarbonyl ylid was employed. In the case of methoxycarbonyl ylid, the yield of alkenoates was poor, even under the more vigorous condition of heating at $160^{\circ} \mathrm{C}$ in a sealed glass tube.

The Wittig reaction product was obtained as a mixture of $(Z)$ - and $(E)$-alkenoate which was separated through an $\mathrm{SiO}_{2}$ column with $3 \%$ ether in hexane. The $(Z)$-isomer was identified by GLC (10\% PEG-20M and FFAP GSCOT columns) and NMR. Methylene protons at $\mathrm{C}_{4}$ of the $(Z)$-2-alkenoate gave a characteristic down-field shift from $\delta 2.1$ to $\delta 2.6$ because of the shielding effect of the ester carbonyl group. This was also observed among both isomers of citral, geranic acid and nerolic acid. $^{8)}$

The 3-ethyl-( $Z$ )-2-alkenyl formates (XI XIV) were prepared following the same procedure, and starting from 3-alkanone and ethoxycarbonyl ylid. This Wittig reaction was done at $160^{\circ} \mathrm{C}$ in a sealed glass tube without using a solvent. Although such a vigorous reaction condition was used, the yield of the alkenoates were poor (total yields of the alkenoates was $22 \sim 28 \%$, based on the ketones employed) and gave a complex mixture of 6 components, from which $(Z)$-2-alkenoate was isolated through an $\mathrm{SiO}_{2}$ column with $3 \%$ ether in hexane.

A typical example of reaction products obtained from 3-nonanone gave the following chromatogram by GLC (FFAP, G-SCOT); peak 1: $12.79 \min (4 \%)$, peak 2: $14.91 \mathrm{~min}$ $(1 \%)$, peak 3: $15.43 \mathrm{~min}(7 \%)$, peak $4: 16.64$ $\min (2 \%)$, peak $5: 17.38 \mathrm{~min}(49 \%)$ and peak 6 : $19.73 \mathrm{~min}(37 \%)$. Peak 5 was identified as $3-$ ethyl-( $Z)$-2-nonenoate and peak 6 was its $(E)$ isomer. Two of the other four components were isolated by an $\mathrm{SiO}_{2}$ column. These two compounds indicated the same molecular weight by GC-MS and showed no UV-absorption band of the conjugated en-one system. Therefore these four compounds were presumed to be double-bond migrated analogues.

The (Z)-2-alkenyl formates $(\mathbf{X V} \sim \mathbf{X V I I})$ were prepared by an alkylation of 1-tetrahydropyranoxy-2-propyne with an appropriate alkyl bromide, hydrolysis to 2-alkyn-1-ol, hydrogenation with Lindlar catalyst and formylation.

For the total of 17 synthetic compounds, including natural pheromone (I) and its synthetic analogue (II), the biological activity was determined. In the Table I, the purities, GLC $t_{R}$ and pheromone activities of these compounds are summarized.

The alarm pheromone activity was demonstrated on 14 compounds, excepting the too long alkyl-chain analogues (IX, X, XIV). The relationship between GLC $t_{R}(\mathrm{OV}-1)$ and biological activity was demonstrated. It seems that vapor pressure for the compound may also be required to develop the activity, based upon the following structural requirement. From the bioassay results, the $(Z)$-allylic primary alcohol formate moiety, with a suitable chain length in a molecule, was elucidated as the basic requisite for developing alarm phero- 
Table I. List of Synthetic Compounds, Purities, GLC $t_{R}$, and Pheromone Activities

\begin{tabular}{lccc}
\hline \multicolumn{1}{c}{ Alkenyl formate } & Purity & Log & $\begin{array}{c}\text { Pheromone } \\
\text { activity } \\
\text { (ppm) }\end{array}$ \\
& & $t_{R}^{*}$ & $1,000 \sim 10,000$ \\
3-Methyl-(Z)-2-heptenyl (III) & 91.8 & 0.041 & $1,000 \sim 10,000$ \\
(Z)-2-Octenyl (XV) & 91.8 & 0.114 & $100 \sim 1,000$ \\
3,6-Dimethyl-(Z)-2-heptenyl (IV) & 81.8 & 0.322 & $100 \sim 1,000$ \\
7-Methyl-(Z)-2-octenyl (XVI) & 100 & 0.322 & $1,000 \sim 10,000$ \\
(Z)-2-Nonenyl (XVII) & 100 & 0.398 & $10 \sim 100$ \\
3-Methyl-(Z)-2-octenyl (V) & 91.1 & 0.398 & $1 \sim 10$ \\
3,7-Dimethyl-(Z)-2-octenyl (II) & 92.8 & 0.602 & $10 \sim 100$ \\
3-Ethyl-(Z)-2-octenyl (XI) & 94.0 & 0.612 & $1 \sim 10$ \\
Neryl (Pheromone) (I) & 100 & 0.653 & $10 \sim 100$ \\
3-Methyl-(Z)-2-nonenyl (VI) & 94.4 & 0.698 & $10 \sim 100$ \\
3-Ethyl-7-methyl-(Z)-2-octenyl (XII) & 80.8 & 0.785 & $100 \sim 1,000$ \\
3,8-Dimethyl-(Z)-2-nonenyl (VII) & 93.3 & 0.806 & $100 \sim 1,000$ \\
3-Ethyl-(Z)-2-nonenyl (XIII) & 80.9 & 0.919 & $100 \sim 1,000$ \\
3-Methyl-(Z)-2-decenyl (VIII) & 94.5 & 0.954 & Inactive \\
3-Ethyl-(Z)-2-decenyl (XIV) & 93.8 & 1.187 & Inactive \\
3-Methyl-(Z)-2-undecenyl (IX) & 94.8 & 1.204 & Inactive \\
3-Methyl-(Z)-2-dodecenyl (X) & 86.0 & 1.462 & \\
\hline
\end{tabular}

* OV $-1,90^{\circ} \mathrm{C}$

mone activity. Substitution of the methyl residue at $C_{3}$ (II, V, VI) enhanced the activity in comparison with the corresponding (Z)-2-alkenyl formates (XV, XVI, XVII). Substitution of the ethyl residue at the $C_{3}$ carbon (XI, XII, XIII) also improved the activity, as did methyl substitution at $\mathrm{C}_{7}$ on the (Z)-2-octenyl formate skeleton (II, XII, XVI). A more detailed discussion on biological activity has been published separately. ${ }^{9 \text { ) }}$

\section{EXPERIMENTAL}

All boiling points were not corrected. Infrared spectra (IR) were recorded on a JASCO IRA-1 grating infrared spectrometer. Mass spectra were measured by a Hitachi GC-MS system, RMU-6MG at $20 \mathrm{eV}$. Nuclear magnetic resonance spectra (NMR) were obtained as a solution in $\mathrm{CDCl}_{3}$ on a JEOL MH-100 (100 MHz) nuclear magnetic resonance spectrometer, using TMS as an internal standard. Gas liquid chromatography (GLC) was carried out using a Yanaco Gas Chromatograph G-180, equipped with a flame ionization detector, with glass columns $(3 \mathrm{~mm}$ i.d. $\times 75 \mathrm{~cm}$ in length) packed with $2 \% \mathrm{OV}-1$ on Chromosorb W, AW-HMDS $\left(60 \sim 80\right.$ mesh) at $90^{\circ} \mathrm{C}$, with $10 \%$ PEG-20M on the same support at each indicated temperature, and with a G-SCOT column $(0.25 \mathrm{~mm}$ i.d. $\times$ $20 \mathrm{~m}$ ) coated with FFAP at $90^{\circ} \mathrm{C}$. The purities of the products were determined by processing the chromatograms with an integrator (SIC Intelligent Integrator Model 7000A). Wako-gel C-200 silicic acid (Wako Pure Chem. Co. Ltd.) was used to separate the ( $Z$ )- and (E)-alkenoate derived from the Wittig reactions and also to purify the compounds. Thin layer chromatography was done using Silica Gel $\mathrm{HF}_{254}$ (E. Merck).

Bioassay. The mold mite, Tyrophagus putrescentiae (Schrank) was used for the bioassay as reported. ${ }^{2)}$ Each compound was dissolved in hexane by a successive ten stage dilution series starting from $10,000 \mathrm{ppm}$. Pheromonal activity was designated by the lowest concentration ( $\mathrm{ppm}$ ) at which mites gave positive response to the tested filter paper. At this critical concentration, the assay was repeated 5 to 10 times.

Neryl formate (I). To the solution of nerol $(3,7-$ dimethyl- $(Z)-2,6$-nonadien-1-ol, $10 \mathrm{~g})$ in pyridine $(50 \mathrm{ml})$, a mixed-anhydride (prepared by mixing formic acid $(98 \%$, $20 \mathrm{ml}$ ) and acetic anhydride $(8 \mathrm{ml})$ at $0^{\circ} \mathrm{C}$ ) was added dropwise at $0^{\circ} \mathrm{C}$, and the mixture kept overnight. This mixture was next poured into iced-water and the product extracted with ether, the ether layer being worked up as usual. After evaporation of the solvent, the residual oil was fractionally distilled to give neryl formate (I), $10 \mathrm{~g}$ $\left(85^{\circ}\right)$, bp $102 \sim 104^{\circ} \mathrm{C}(15 \mathrm{mmHg})$. IR $v_{\max }^{\mathrm{film}} \mathrm{cm}^{-1} 1720$ $(\mathrm{C}=\mathrm{O}), 1665(\mathrm{C}=\mathrm{C})$ and $1160(\mathrm{C}-\mathrm{O}-\mathrm{C}), \mathrm{NMR} \delta ; 1.60$ $(3 \mathrm{H}, \mathrm{s}), 1.68(3 \mathrm{H}, \mathrm{s}), 1.78(3 \mathrm{H}, \mathrm{s}), 2.0 \sim 2.2(4 \mathrm{H}, \mathrm{br}), 4.65$ $(2 \mathrm{H}, \mathrm{d}), 5.10(1 \mathrm{H}$, br. s), $5.38(1 \mathrm{H}, \mathrm{t})$ and $8.08(\mathrm{lH}, \mathrm{s})$. $\mathrm{GLC}_{120^{\circ} \mathrm{C}}^{\mathrm{PEG}-2 \mathrm{M}} t_{R} ; 6.50 \mathrm{~min}$, purity; $100 \%$. 
3,7-Dimethyl-(Z)-2-octenyl formate (II). Details of the synthetic procedure and physico-chemical data have already been reported. ${ }^{4)}$

3-Methyl-(Z)-2-heptenyl formate (III). A mixture of 2hexanone $(3 \mathrm{~g})$ and ethoxycarbonyl ylid $(10.4 \mathrm{~g})$ was heated at $150^{\circ} \mathrm{C}$ overnight without a solvent. After cooling to room temperature, hexane was added and the resulting crystalline mass removed by filtration through an $\mathrm{SiO}_{2}$ $(10 \mathrm{~g})$ column, which was subsequently washed with benzene. The combined filtrate and washings were concentrated in vacuo and the residual oil was fractionally distilled to give ethyl 3-methyl-2-heptenoate, $2.3 \mathrm{~g} \mathrm{(41 \% ),}$ bp $115 \sim 117^{\circ} \mathrm{C}(43 \mathrm{mmHg})$, a mixture of geometric isomers $(Z ; 29 \%$ and $E ; 71 \%)$. Both isomers were separated on an $\mathrm{SiO}_{2}$ column by eluting with $3 \%$ ether in hexane. The $(Z)$-isomer gave a higher $R_{\mathrm{f}}$ than the $(E)$-isomer and was recovered from the column first. NMR, $(E)$-isomer $\delta$; $0.91(3 \mathrm{H}, \mathrm{t}), 1.26(3 \mathrm{H}, \mathrm{t}, 7 \mathrm{~Hz}), 1.2 \sim 1.6(4 \mathrm{H}$, br. $\mathrm{m}), 2.10$ $(3 \mathrm{H}, \mathrm{d}, 1 \mathrm{~Hz}), \mathrm{ca} .2 .1(2 \mathrm{H}, \mathrm{br} . \mathrm{t}), 4.12(2 \mathrm{H}, \mathrm{q}, 7 \mathrm{~Hz})$ and $5.63(1 \mathrm{H}$, br. $\mathrm{s}),(Z)$-isomer $\delta ; 0.91(3 \mathrm{H}, \mathrm{t}), 1.26(3 \mathrm{H}, \mathrm{t}$, $7 \mathrm{~Hz}), 1.2 \sim 1.6(4 \mathrm{H}$, br. $\mathrm{m}), 1.86(3 \mathrm{H}, \mathrm{d}, 1 \mathrm{~Hz}), 2.60(2 \mathrm{H}$, br. t), $4.12(2 \mathrm{H}, \mathrm{q})$ and $5.63(1 \mathrm{H}$, br. s).

To an ether solution of ethyl 3-methyl- $(Z)$-2-heptenoate $(0.6 \mathrm{~g})$, an adequate quantity of $\mathrm{LiAlH}_{3}(\mathrm{OEt})$ in ether was added dropwise at $0^{\circ} \mathrm{C}$. After decomposing the excess reagent with iced-water, the product was extracted with ether and the ether layer worked up as usual. After evaporation of the solvent, the residual oil was purified through an $\mathrm{SiO}_{2}$ column to give 3-methyl- $(Z)$-2-hepten-1ol, $0.37 \mathrm{~g}(90 \%)$. NMR $\delta ; 0.91(3 \mathrm{H}, \mathrm{t}), 1.1 \sim 1.5(4 \mathrm{H}$, br. $\mathrm{m}), 1.42(1 \mathrm{H}, \mathrm{s}), 1.72(3 \mathrm{H}, \mathrm{s}), 2.02(2 \mathrm{H}$, br. t $), 4.07(2 \mathrm{H}, \mathrm{d}$, $7 \mathrm{~Hz})$ and $5.36(1 \mathrm{H}, \mathrm{t}, 7 \mathrm{~Hz})$.

The alcohol was converted to the formate (III) as above and purified through an $\mathrm{SiO}_{2}$ column. IR $v_{\max }^{\mathrm{film}} \mathrm{cm}^{-1} ; 1720$ $(\mathrm{C}=\mathrm{O}), 1660(\mathrm{C}=\mathrm{C})$ and $1150(\mathrm{C}-\mathrm{O}-\mathrm{C}) . \mathrm{NMR} \delta ; 0.90$ $(3 \mathrm{H}, \mathrm{t}), 1.34(4 \mathrm{H}, \mathrm{br}), 1.76(3 \mathrm{H}, \mathrm{s}), 2.09(2 \mathrm{H}, \mathrm{t}), 4.63(2 \mathrm{H}$, $\mathrm{d}, 8 \mathrm{~Hz}), 5.33(1 \mathrm{H}, \mathrm{t}, 8 \mathrm{~Hz})$ and $8.03(1 \mathrm{H}, \mathrm{s}) \mathrm{GLC}_{120^{\circ} \mathrm{C}}^{\mathrm{PEG}-20 \mathrm{M}} t_{R}$; $2.17 \mathrm{~min}$, purity; $98.6 \%$.

3,6-Dimethyl-(Z)-2-heptenyl formate (IV). 5-Methyl-2hexanone $(3.4 \mathrm{~g})$ was reacted with ethoxycarbonyl ylid $(10.4 \mathrm{~g})$ as above to give the ethyl ester, $3.5 \mathrm{~g}(61 \%), \mathrm{bp}$ $118 \sim 120^{\circ} \mathrm{C}(37 \mathrm{mmHg})(Z ; 40 \%$ and $E ; 60 \%)$. The $(Z)-$ isomer was treated as above and converted to the formate (IV). IR $v_{\max }^{\text {film }} \mathrm{cm}^{-1} ; 1722(\mathrm{C}=\mathrm{O}), 1660(\mathrm{C}=\mathrm{C})$ and 1155 (C-O-C). NMR $\delta ; 0.90(6 \mathrm{H}, \mathrm{d}, 7 \mathrm{~Hz}), 1.27(2 \mathrm{H}, \mathrm{m}), 1.75$ $(3 \mathrm{H}, \mathrm{s}), 2.07(2 \mathrm{H}$, br. t, $8 \mathrm{~Hz}), 4.63(2 \mathrm{H}, \mathrm{d}, 8 \mathrm{~Hz}), 5.32(1 \mathrm{H}$, $\mathrm{t}, 8 \mathrm{~Hz})$ and $8.04(1 \mathrm{H}, \mathrm{s}) . \mathrm{GLC}_{120^{\circ} \mathrm{C}}^{\mathrm{PEG}} t_{R} ; 2.61 \mathrm{~min}$, purity; $81.8 \%$.

3-Methyl-(Z)-2-octenyl formate (V). 2-Heptanone $(3.4 \mathrm{~g})$ was reacted as above to give the ethyl ester, $3.1 \mathrm{~g}$ $(57 \%)$, bp $121 \sim 125^{\circ} \mathrm{C}(34 \mathrm{mmHg})(Z ; 38 \%$ and $E ; 62 \%)$. The $(Z)$-isomer was treated as above and converted to the formate (V). IR $v_{\max }^{\mathrm{film}} \mathrm{cm}^{-1} ; 1720(\mathrm{C}=\mathrm{O}), 1663(\mathrm{C}=\mathrm{C})$ and $1157(\mathrm{C}-\mathrm{O}-\mathrm{C})$. NMR $\delta ; 0.89(3 \mathrm{H}, \mathrm{t}), 1.29(6 \mathrm{H}, \mathrm{br}), 1.75$
$(3 \mathrm{H}, \mathrm{s}), 2.08(2 \mathrm{H}$, br. t, $8 \mathrm{~Hz}), 4.64(2 \mathrm{H}, \mathrm{d}, 8 \mathrm{~Hz}), 5.33(1 \mathrm{H}$, $\mathrm{t}, 8 \mathrm{~Hz})$ and $8.04(1 \mathrm{H}, \mathrm{s}) . \mathrm{GLC}_{120^{\circ} \mathrm{C}}^{\mathrm{PEG}} t_{R} ; 3.24 \mathrm{~min}$, purity; $91.4 \%$.

3-Methyl-(Z)-2-nonenyl formate (VI). 2-Octanone $(3.9 \mathrm{~g})$ was reacted as above to give the ethyl ester, $4.0 \mathrm{~g}$ $(66 \%)$, bp $139 \sim 142^{\circ} \mathrm{C}(38 \mathrm{mmHg})(Z ; 37.7 \%$ and $E$; $62.3 \%$ ). The $(Z)$-isomer was treated as above and converted to the formate (VI). IR $v_{\max }^{\mathrm{film}} \mathrm{cm}^{-1} ; 1720(\mathrm{C}=\mathrm{O})$, $1622(\mathrm{C}=\mathrm{C})$ and $1150(\mathrm{C}-\mathrm{O}-\mathrm{C})$. NMR $\delta ; 0.88(3 \mathrm{H}, \mathrm{t})$, $1.29(8 \mathrm{H}, \mathrm{br}), 1.75(3 \mathrm{H}, \mathrm{s}), 2.10(2 \mathrm{H}$, br. t), $4.64(2 \mathrm{H}, \mathrm{d}$, $8 \mathrm{~Hz}), 5.34(\mathrm{IH}, \mathrm{t}, 8 \mathrm{~Hz})$ and $8.04(1 \mathrm{H}, \mathrm{s}) . \mathrm{GLC}_{120^{\circ} \mathrm{C}}^{\mathrm{PEG}-\mathrm{M}} t_{R}$; $5.08 \mathrm{~min}$, purity; $94.4 \%$.

3-Methyl-(Z)-2-decenyl formate (VIII). 2-Nonanone $(4.3 \mathrm{~g})$ was reacted as above to give the ethyl ester, $3.4 \mathrm{~g}$ $(53 \%)$, bp $148 \sim 153^{\circ} \mathrm{C}(38 \mathrm{mmHg})(Z ; 37.7 \%$ and $E$; $62.3 \%$ ). The $(Z)$-isomer was treated as above and converted to the formate (VIII). IR $v_{\max }^{\mathrm{fim}} \mathrm{cm}^{-1} ; 1720(\mathrm{C}=\mathrm{O})$, $1662(\mathrm{C}=\mathrm{C})$ and $1160(\mathrm{C}-\mathrm{O}-\mathrm{C})$. NMR $\delta ; 0.89(3 \mathrm{H}, \mathrm{t})$, $1.29(10 \mathrm{H}$, br $), 1.75(3 \mathrm{H}, \mathrm{s}), 2.09(2 \mathrm{H}$, br. t, $8 \mathrm{~Hz}), 4.65$ $(2 \mathrm{H}, \mathrm{d}, 8 \mathrm{~Hz}), 5.35(1 \mathrm{H}, \mathrm{t}, 8 \mathrm{~Hz})$ and $8.04(1 \mathrm{H}, \mathrm{s})$. GLC $_{120^{\circ} \mathrm{C}}^{\text {PEG-M }} t_{R} ; 8.37 \mathrm{~min}$, purity; $94.5 \%$.

3,8-Dimethyl-(Z)-nonenyl formate (VII). 7-Methyl-2octanone $(12 \mathrm{~g})$ and methoxycarbonyl ylid $(38 \mathrm{~g})$ were heated in a sealed glass tube overnight at $160^{\circ} \mathrm{C}$. The $(Z)$ and $(E)$-isomers of the nonenoate were separated by an $\mathrm{SiO}_{2}$ column to give the $(Z)$-isomer $(1.59 \mathrm{~g}), \mathrm{GLC}_{120^{\circ} \mathrm{C}}^{\mathrm{PEG}}$ $t_{R} ; 3.5 \mathrm{~min}, \mathrm{IR} v_{\max }^{\mathrm{film}} \mathrm{cm}^{-1} ; 1718(\mathrm{C}=\mathrm{O})$ and $1640(\mathrm{C}=\mathrm{C})$, and a mixture of the $(Z)$ - and $(E)$-isomers $(4.88 \mathrm{~g})$. The $(Z)$-isomer was reduced to $(Z)$-alcohol $(1.21 \mathrm{~g}$, GLC $\left._{130^{\circ} \mathrm{C}}^{\mathrm{PEG}-20 \mathrm{M}} t_{R} ; 7.7 \mathrm{~min}\right)$ and converted to the formate (VII, 0.95 g). IR $v_{\max }^{\mathrm{film}} \mathrm{cm}^{-1} ; 1720(\mathrm{C}=\mathrm{O}), 1660(\mathrm{C}=\mathrm{C})$ and $1150(\mathrm{C}-\mathrm{O}-\mathrm{C})$. NMR $\delta ; 0.85(3 \mathrm{H}, \mathrm{t}), 1.26(6 \mathrm{H}, \mathrm{br}), 1.75$ $(3 \mathrm{H}, \mathrm{s}), 2.09(2 \mathrm{H}$, br. t) $4.66(2 \mathrm{H}, \mathrm{d}, 8 \mathrm{~Hz}), 5.33(1 \mathrm{H}, \mathrm{t}$, $8 \mathrm{~Hz})$ and $8.02(1 \mathrm{H}, \mathrm{s}) . \mathrm{GLC}_{120^{\circ} \mathrm{C}}^{\mathrm{PEG}} t_{R} ; 6.6 \mathrm{~min}$, purity; $93.3 \%$.

3-Methyl-(Z)-2-undecenyl formate (IX). 2-Decanone $(7.7 \mathrm{~g})$ was reacted with methoxycarbonyl ylid $(16.5 \mathrm{~g})$ as in the case of VII. The isolated $(Z)$-isomer $(0.446 \mathrm{~g})$ was reduced and converted to the formate (IX). $0.31 \mathrm{~g}(69 \%$ from ester to formate). IR $v_{\max }^{\mathrm{film}} \mathrm{cm}^{-1} ; 1718(\mathrm{C}=\mathrm{O}), 1655$ $(\mathrm{C}=\mathrm{C})$ and $1150(\mathrm{C}-\mathrm{O}-\mathrm{C})$. NMR $\delta ; 0.87(3 \mathrm{H}, \mathrm{t}), 1.28$ $(10 \mathrm{H}, \mathrm{br}), 1.77(3 \mathrm{H}, \mathrm{s}), 2.08(2 \mathrm{H}$, br. t, $8 \mathrm{~Hz}), 4.66(2 \mathrm{H}, \mathrm{d}$, $8 \mathrm{~Hz}), 5.33(1 \mathrm{H}, \mathrm{t}, 8 \mathrm{~Hz})$ and $8.0(1 \mathrm{H}, \mathrm{s}) . \mathrm{GLC}_{120^{\circ} \mathrm{C}}^{\mathrm{PEG}-\mathrm{M}} t_{R}$; $13.85 \mathrm{~min}$, purity; $94.8 \%$.

3-Methyl-(Z)-2-dodecenyl formate (X). 2-Undecanone $(7.8 \mathrm{~g})$ was reacted with methoxycarbonyl ylid $(16 \mathrm{~g})$ as above to give $(Z)$-isomer $(1.05 \mathrm{~g})$ after separation by an $\mathrm{SiO}_{2}$ column. This was reduced and converted to the formate $(\mathbf{X})$. IR $v_{\max }^{\mathrm{film}} \mathrm{cm}^{-1} ; 1718(\mathrm{C}=\mathrm{O}), 1655(\mathrm{C}=\mathrm{C})$ and 1145 (C-O-C). NMR $\delta ; 0.87(3 \mathrm{H}, \mathrm{t}), 1.28(14 \mathrm{H}, \mathrm{br}), 1.75$ $(3 \mathrm{H}, \mathrm{s}), 2.08(2 \mathrm{H}$, br. $\mathrm{t}, 8 \mathrm{~Hz}), 4.67(2 \mathrm{H}, \mathrm{d}, 8 \mathrm{~Hz}), 5.35(1 \mathrm{H}$, $\mathrm{t}, 8 \mathrm{~Hz})$ and $8.03(1 \mathrm{H}, \mathrm{s}) . \mathrm{GLC}_{120^{\circ} \mathrm{C}}^{\mathrm{PEG}} t_{R} ; 22.8 \mathrm{~min}$, purity; 
$86 \%$.

3-Ethyl-(Z)-2-octenyl formate (XI). 3-Octanone (3.9 g) was reacted with ethoxycarbonyl ylid $(10.4 \mathrm{~g})$ in a sealed glass tube at $160^{\circ} \mathrm{C}$ overnight. To the mixture at room temperature, hexane was added and the hexane-soluble was filtered through an $\mathrm{SiO}_{2}$ layer. The layer was washed with benzene, the filtrate and washings combined and the solvent then evaporated. The residual oil was fractionally distilled. After recovery of the unreacted ketone, the ester $(1.7 \mathrm{~g}, 28 \%$ from the starting ketone) was obtained, bp $100 \sim 109^{\circ} \mathrm{C}(21 \mathrm{mmHg})$, which consisted of $6 \mathrm{com}-$ ponents. Two components $(85 \%)$ were $(Z)$ - and $(E)-2-$ octenoate $(Z ; 56 \%$ and $E ; 44 \%)$ and the other four $(15 \%)$ were double-bond migrated analogues. The (Z)-2octenoate was isolated as the first eluted fraction from the mixture by an $\mathrm{SiO}_{2}$ column with $3 \%$ ether in hexane. This was reduced and converted to the formate $(\mathrm{XI})$. IR $v_{\max }^{\text {film }}$ $\mathrm{cm}^{-1} ; 1720(\mathrm{C}=\mathrm{O}), 1660(\mathrm{C}=\mathrm{C})$ and $1150(\mathrm{C}-\mathrm{O}-\mathrm{C})$. NMR $\delta ; 0.93(3 \mathrm{H}, \mathrm{t}), 1.05(3 \mathrm{H}, \mathrm{t}), 1.33(6 \mathrm{H}$, br. $\mathrm{t}), 2.09$ $(2 \mathrm{H}, \mathrm{q}), 2.13(2 \mathrm{H}, \mathrm{t}), 4.70(2 \mathrm{H}, \mathrm{d}), 5.33(1 \mathrm{H}, \mathrm{t})$ and 8.04 $(1 \mathrm{H}, \mathrm{s}) . \mathrm{GLC}_{120^{\circ} \mathrm{C}}^{\mathrm{PEG}-2 \mathrm{M}} t_{R} ; 4.69 \mathrm{~min}$, purity; $94 \%$.

3-Ethyl,7-methyl-(Z)-2-octenyl formate (XII). 7Methyl-3-octanone $(7.1 \mathrm{~g})$ was reacted with ethoxycarbonyl ylid $(17.3 \mathrm{~g})$ as above to give a mixture of the ester $(1.2 \mathrm{~g})$. The isolated $(Z)$-isomer $(0.5 \mathrm{~g})$ was reduced and converted to the formate (XII, $80 \mathrm{mg})$. IR $v_{\max }^{\mathrm{fim}} \mathrm{cm}^{-1}$; $1720(\mathrm{C}=\mathrm{O}), 1660(\mathrm{C}=\mathrm{C})$ and $1150(\mathrm{C}-\mathrm{O}-\mathrm{C})$. NMR $\delta$; $0.85(6 \mathrm{H}, \mathrm{d}), 1.04(3 \mathrm{H}, \mathrm{t}), 1.26(4 \mathrm{H}, \mathrm{m}), 2.06(2 \mathrm{H}, \mathrm{q}), 2.09$ $(2 \mathrm{H}, \mathrm{t}), 4.69(2 \mathrm{H}, \mathrm{d}), 5.31(1 \mathrm{H}, \mathrm{t}, 8 \mathrm{~Hz})$ and $8.03(1 \mathrm{H}, \mathrm{s})$. $\mathrm{GLC}_{120^{\circ} \mathrm{C}}^{\mathrm{PEG}-2 \mathrm{MM}} t_{R} ; 5.85 \mathrm{~min}$, purity; $80.8 \%$.

3-Ethyl-(Z)-2-nonenyl formate (XIII). 3-Nonanone $(4.3 \mathrm{~g})$ and ethoxycarbonyl ylid $(10.4 \mathrm{~g})$ were reacted as above. The distilled fraction, bp $118 \sim 120^{\circ} \mathrm{C}(12 \mathrm{mmHg})$, $1.6 \mathrm{~g}(25 \%)$, consisted of 6 components, of which 2 components $(86 \%)$ were $(Z)$ - and $(E)$-ester $(Z ; 57 \%$ and $E ; 43 \%)$ and the 4 other components $(14 \%)$ were doublebond migrated analogues. The isolated $(Z)$-ethyl ester $(0.9 \mathrm{~g})$ from an $\mathrm{SiO}_{2}$ column was reduced and converted to the formate (XIII), 0.35g. IR $v_{\max }^{\mathrm{film}} \mathrm{cm}^{-1} ; 1720(\mathrm{C}=\mathrm{O})$, $1660(\mathrm{C}=\mathrm{C})$ and $1150(\mathrm{C}-\mathrm{O}-\mathrm{C})$. NMR $\delta ; 0.87(3 \mathrm{H}, \mathrm{t})$, $1.00(3 \mathrm{H}, \mathrm{t}), 1.28(3 \mathrm{H}, \mathrm{br}), 2.06(2 \mathrm{H}, \mathrm{q}), 2.11(2 \mathrm{H}, \mathrm{t}), 4.68$ $(2 \mathrm{H}, \mathrm{d}), 5.31(1 \mathrm{H}, \mathrm{t}, 8 \mathrm{~Hz})$ and $8.03(1 \mathrm{H}, \mathrm{s}) . \mathrm{GLC}_{120^{\circ} \mathrm{C}}^{\mathrm{PEG}-20 \mathrm{M}} t_{R}$; $7.56 \mathrm{~min}$, purity; $80.9 \%$.

3-Ethyl-(Z)-2-decenyl formate (XIV). 3-Decanone $(4.6 \mathrm{~g})$ and ethoxycarbonyl ylid $(10.4 \mathrm{~g})$ were reacted as above. The distilled fraction, bp $125 \sim 128^{\circ} \mathrm{C}(11 \mathrm{mmHg})$, $1.5 \mathrm{~g}(22 \%)$, consisted of 6 components, of which 2 components $(93 \%)$ were $(Z)$ - and $(E)$-ester $(Z ; 56 \%$ and $E ; 44 \%$ ) and the 4 other components $(7 \%)$ were doublebond migrated analogues. The isolated $(Z)$-ester from an $\mathrm{SiO}_{2}$ column was reduced and converted to the formate (XIV). IR $v_{\max }^{\text {film }} \mathrm{cm}^{-1} ; 1719(\mathrm{C}=\mathrm{O}), 1660(\mathrm{C}=\mathrm{C})$ and $1148(\mathrm{C}-\mathrm{O}-\mathrm{C})$. NMR $\delta ; 0.88(3 \mathrm{H}, \mathrm{t}), 1.02(3 \mathrm{H}, \mathrm{t}), 1.27$
$(10 \mathrm{H}$, br $), 2.06(2 \mathrm{H}, \mathrm{q}), 2.10(2 \mathrm{H}, \mathrm{t}), 4.69(2 \mathrm{H}, \mathrm{d}), 5.32(1 \mathrm{H}$, t) and $8.05(1 \mathrm{H}, \mathrm{s}) . \mathrm{GLC}_{120^{\circ} \mathrm{C}}^{\mathrm{PEG}-2 \mathrm{M}} t_{R} ; 12.09 \mathrm{~min}$, purity; $93.8 \%$.

7-Methyl-(Z)-2-octenyl formate (XVI). Under a $\mathrm{N}_{2}$ atmosphere, 4-methyl-pentyl bromide (16g) in HMPA $(50 \mathrm{ml})$ was added dropwise at $0^{\circ} \mathrm{C}$ to a mixture of 1 tetrahydropyranyloxy-2-propyne $(14 \mathrm{~g})$ in THF $(50 \mathrm{ml})$ and an equimolar amount of $15 \% n$-butyllithium in hexane. This mixture was kept at room temperature overnight, and after the usual work-up, the product was extracted with ether. After evaporation of the solvent and fractional distillation, the unreacted tetrahydropyranyl ether was removed $\left[93 \sim 94^{\circ} \mathrm{C}(71 \mathrm{mmHg})\right]$. The remaining residue was purified through an $\mathrm{SiO}_{2}$ column to give 7 methyl-1-tetrahydropyranyloxy-2-octyne, $\mathrm{GLC}_{160^{\circ} \mathrm{C}}^{\mathrm{PEG}} t_{R} ; 7.5 \mathrm{~min}$.

This ester $(4.3 \mathrm{~g})$ was dissolved in $\mathrm{MeOH}(100 \mathrm{ml})$ containing TsOH (100 mg). After refluxing for $1 \mathrm{hr}$, $\mathrm{Na}_{2} \mathrm{CO}_{3}$ was directly added. After evaporation of the solvent in vacuo, the residue was extracted with ether and worked up as usual to give 7-methyl-2-octyn-1-ol (1.03 g). $\mathrm{GLC}_{130^{\circ} \mathrm{C}}^{\mathrm{PEG}-2 \mathrm{M}} t_{R} ; 10.3 \mathrm{~min}$.

This alcohol $(1.03 \mathrm{~g})$ was dissolved in hexane $(80 \mathrm{ml})$ and hydrogenated over a Lindlar catalyst $(100 \mathrm{mg})$. After removing the catalyst and evaporating the solvent, 7 methyl-( $Z)$-2-octen-1-ol $(0.88 \mathrm{~g})$ was obtained. $\mathrm{GLC}_{130^{\circ} \mathrm{C}}^{\mathrm{PEG}} t_{R} ; 4.3 \mathrm{~min}$. The resulting alcohol was converted to the formate (XVI), $0.56 \mathrm{~g}$. IR $v_{\max }^{\mathrm{film}} \mathrm{cm}^{-1} ; 1722$ $(\mathrm{C}=\mathrm{O}), 1665(\mathrm{C}=\mathrm{C}$, weak) and $1160(\mathrm{C}-\mathrm{O}-\mathrm{C})$. NMR $\delta$; $0.86(6 \mathrm{H}, \mathrm{d}), 1.68 \sim 1.04(4 \mathrm{H}, \mathrm{m}), 2.09(2 \mathrm{H}, \mathrm{d} . \mathrm{t}), 4.69(2 \mathrm{H}$, d), $5.57(2 \mathrm{H}, \mathrm{m}, 6 \mathrm{~Hz}, 12 \mathrm{~Hz})$ and $8.04(1 \mathrm{H}, \mathrm{s}) . \mathrm{GLC}_{120^{\circ} \mathrm{C}}^{\mathrm{PEG}}$ $t_{R} ; 3.07 \mathrm{~min}$, purity; $100 \%$.

(Z)-2-octenyl formate ( $\mathrm{XV}$ ). Under an $\mathrm{N}_{2}$ atmosphere, 1-tetrahydropyranyloxy-2-propyne $(9 \mathrm{~g})$ was alkylated with $n$-amyl bromide $(9.5 \mathrm{~g})$ as above, and the alkylation product was subsequently hydrolyzed to 2-octyn-1-ol $(0.47 \mathrm{~g})$. After hydrogenation over a Lindlar catalyst, the alcohol was converted to the formate $(\mathrm{XV}), 0.19 \mathrm{~g}$. IR $v_{\max }^{\mathrm{fijm}}$ $\mathrm{cm}^{-1} ; 1720(\mathrm{C}=\mathrm{O}), 1650 \quad(\mathrm{C}=\mathrm{C}$, weak $)$ and 1160 $(\mathrm{C}-\mathrm{O}-\mathrm{C})$. NMR $\delta ; 0.90(3 \mathrm{H}, \mathrm{t}), 1.32(6 \mathrm{H}, \mathrm{br}), 2.10(2 \mathrm{H}, \mathrm{d}$. t), $4.72(2 \mathrm{H}, \mathrm{d}, 6 \mathrm{~Hz}), 5.59(2 \mathrm{H}, \mathrm{m}, 6 \mathrm{~Hz}, 12 \mathrm{~Hz})$ and 8.32 $(1 \mathrm{H}, \mathrm{s}) . \mathrm{GLC}_{120^{\circ} \mathrm{C}}^{\mathrm{PEG}} t_{R} ; 2.2 \mathrm{~min}$, purity; $91.8 \%$.

(Z)-2-Nonenyl formate (XVII). By the same method and scale as in the case of XVI, 1-tetrahydropyranyloxy-2nonyne $(4.5 \mathrm{~g})$ was obtained, which was converted to the alcohol and subsequently to $(Z)-2$-nonen-1-ol (1.5 g). This alcohol was converted to the formate (XVII), $0.94 \mathrm{~g}$. IR $v_{\max }^{\mathrm{film}} \mathrm{cm}^{-1} ; 1721(\mathrm{C}=\mathrm{O}), 1650(\mathrm{C}=\mathrm{C}$, weak $)$ and 1158 (C-O-C). NMR $\delta ; 0.87(3 \mathrm{H}, \mathrm{t}), 1.32(8 \mathrm{H}, \mathrm{br}), 2.10(2 \mathrm{H}, \mathrm{d}$. t), $4.84(2 \mathrm{H}, \mathrm{d}), 5.60(2 \mathrm{H}, \mathrm{m}, 6 \mathrm{~Hz}, 12 \mathrm{~Hz})$ and $8.05(1 \mathrm{H}, \mathrm{s})$. $\mathrm{GLC}_{120^{\circ} \mathrm{C}}^{\mathrm{PEG}-2 \mathrm{M}} t_{R} ; 3.79 \mathrm{~min}$, purity; $100 \%$. 


\section{REFERENCES}

1) Y. Kuwahara, S. Ishii and H. Fukami, Experientia, 31, 1115 (1975).

2) Y. Kuwahara, H. Fukami, S. Ishii, K. Matsumoto and Y. Wada, Jap. J. Sanit. Zool., 30, 309 (1979).

3) L. T. My-Yen, K. Matsumoto, Y. Wada and $Y$. Kuwahara, Appl. Entomol. Zool., 15, 474 (1980).

4) Y. Kuwahara, Appl. Entomol. Zool., 17, 127 (1982).

5) R. S. Davidson, W. H. H. Gunther, S. M. Waddington-Feather and B. Lythgoe, J. Chem. Soc., 1964, 4907 (1964).
6) F. Reber, A. Lardon and T. Reichstein, Helv. Chim. Acta, 37, 45 (1954).

7) L. D. Bergelson and M. M. Shemyakin, "Newer Methods of Preparative Organic Chemistry," Vol. V, ed. by W. Foerst, Academic Press, New York, 1968, p. 157.

8) A. A. Swigar and R. M. Silverstein, "Monoterpenes," Aldrich Chem. Co., Inc. Milwaukee, 1981 , pp. 35, 36, 74 and 76.

9) Y. Kuwahara and L. Sakuma, Appl. Entomol. Zool., 17, 263 (1982). 